\title{
Hubungan Antara Kecerdasan Emosi Dengan Stres Kerja Pada Perawat
}

\author{
Correlation Between Emotional Intelligence and \\ Occupational Stress Among Nurses
}

\author{
Devy Yurista, Abu Bakar, Mirza \\ Program Studi Psikologi, Fakultas Kedokteran, Universitas Syiah Kuala, Banda Aceh, 23111 \\ E-mail: devy.psikologi@gmail.com
}

\begin{abstract}
KATA KUNCI Kecerdasan Emosi, Stres Kerja, Perawat
KEYWORDS Emotional Intelligence, Occupational Stress, Nurses
\end{abstract}

ABSTRAK Perawat merupakan tenaga kesehatan paling lama yang berhubungan dengan pasien, berhadapan dengan pasien yang penyakitnya beragam dan tuntutan pekerjaan dapat menjadi salah satu sumber stres yang kuat pada perawat dalam bekerja sehingga dibutuhkan kecerdasan emosi. Penelitian ini bertujuan untuk mengetahui hubungan antara kecerdasan emosi dengan stres kerja pada perawat di Rumah Sakit Jiwa Banda Aceh. Hasil penelitian ini diharapkan dapat menjadi bahan masukan dan evaluasi bagi pihak Rumah Sakit Jiwa dalam upaya meningkatkan kualitas pelayanan kesehatan dengan menerapkan kecerdasan emosi dalam menurunkan stres kerja pada perawat. Subjek penelitian adalah 100 perawat yang terlibat langsung dalam memberikan asuhan keperawatan jiwa pada pasien. Metode pengumpulan data menggunakan skala kecerdasan emosi sebanyak 29 aitem dan skala stres kerja 33 aitem yang disusun sendiri oleh peneliti. Analisa data menggunakan teknik korelasi Pearson dari statistik parametrik dengan koefisien korelasi $r=-0.584$ dan $p=0.00$, $(p<0.01)$. Hasil penelitian menunjukkan terdapat korelasi negatif signifikan antara kecerdasan emosi dengan stres kerja pada perawat yang berarti semakin tinggi kecerdasan emosi maka semakin rendah stres kerja, begitu pula sebaliknya semakin rendah kecerdasan emosi maka semakin tinggi stres kerja yang dialami oleh perawat tersebut.

ABSTRACT Health worker like nurses have the longest contact with patients. Emotional intelligence is needed when interacting with the patients with variety of diseases and work demand that become one of the sources of stress in nurses. This research aims to figure out the relationship between emotional intelligence and occupational stress on nurses at psychiatric hospital in Banda Aceh. The participants were 100 nurses that involved in taking care of the patients. Emotional intelligence scale consisting of 29 items and occupational stress scale of 33 items were employed for data collection. Pearson correlation of parametric statistics with correlation coefficient $r=-0.584$ and $p=0.00,(p<0.01)$ was used for data analysis. The result of the study shows negative significant correlation between emotional intelligence and occupational stress on nurses. Therefore, the higher emotional intelligence the lower occupational stress; likewise, the lower emotional intelligence the higher occupational stress faced by the nurses. 
PENDAHULUAN

Peningkatan angka penderita gangguan kejiwaan terjadi hampir diberbagai daerah termasuk di Provinsi Aceh. Bencana alam salah satunya tsunami dan konflik yang terjadi di Aceh dinilai sebagai penyebab utama terjadinya gangguan kejiwaan (Maysarah, 2008). Data yang dihimpun dari bagian humas Rumah Sakit Jiwa Banda Aceh, menyebutkan jumlah pasien yang masuk yang menjalani perawatan sepanjang tahun 2008 sebanyak 2.306 orang, tahun 2009 sebanyak 2.316 orang, tahun 2010 sebanyak 2.141 orang dan tahun 2011 mencapai 2.658 orang.

Pasien yang dirujuk ke Rumah Sakit Jiwa Banda Aceh terdiri dari berbagai jenis penyakit kejiwaan. Pada tahun 2011, penyakit yang paling banyak dirujuk adalah skizoprenia dengan jumlah 13.587 orang. Diikuti oleh penyakit gangguan mental dan perilaku zat sebanyak 898 orang. Data 10 jenis penyakit atau diagnosa bagi pasien yang menjalani rawat jalan dan rawat inap di Rumah Sakit Jiwa Banda Aceh tahun 2011 dapat dilihat pada tabel dibawah ini.

Tabel. 1 Data statistik 10 Jenis Penyakit/Diagnosa Bagi Pasien Yang Masuk Rumah Sakit Jiwa Banda Aceh tahun 2011

\begin{tabular}{lllll}
\hline No & Penyakit/Diagnosa & $\begin{array}{l}\text { Rawat } \\
\text { Jalan }\end{array}$ & $\begin{array}{l}\text { Rawat } \\
\text { Inap }\end{array}$ & Jumlah \\
\hline 1. & Skizoprenia & 10.389 & 1.599 & 13.587 \\
2. & Gangguan mental dan perilaku akibat zat & 474 & 212 & 898 \\
3. & Gangguan suasana perasaan & 435 & 46 & 481 \\
4. & Epilepsi & 204 & 82 & 286 \\
5. & Gangguan neurotik & 164 & 24 & 188 \\
6. & Gangguan mental organik & 163 & 4 & 167 \\
7. & Gangguan jiwa yang tak tergolongkan & 81 & - & 81 \\
8. & Gangguan perilaku dan emosional kanak- & & & \\
& kanak dan remaja & 29 & - & 29 \\
& Sindroma perilaku yang berhubungan & 16 & 11 & 27 \\
9. dengan psikologis & 17 & - & 17 \\
10. & Gangguan perkembangan psikologis & $\mathbf{1 1 . 9 7 2}$ & $\mathbf{1 . 9 8 2}$ & $\mathbf{1 3 . 9 5 4}$ \\
\hline
\end{tabular}

Sumber: Rumah Sakit Jiwa Banda Aceh Tahun 2012

Rumah Sakit Jiwa Banda Aceh merupakan rumah sakit rujukan tertinggi di tingkat Provinsi Aceh, sehingga setiap pasien yang mengalami gangguan jiwa yang ada di kabupaten/kota ataupun kecamatan akan dirujuk ke Rumah Sakit Jiwa Banda Aceh dan sebagai salah satu rumah sakit pemerintah yang menerima pasien Jaminan Kesehatan Aceh (JKA), tentunya mempunyai beban tersendiri untuk bisa memberikan pelayanan kesehatan yang bermutu kepada masyarakat di provinsi Aceh. Adanya program pemerintah yaitu Jaminan Kesehatan Aceh (JKA) mengakibatkan jumlah kunjungan pasien untuk berobat di Rumah Sakit Jiwa saat ini mengalami peningkatan dari sebelumnya sehingga perawat mengalami peningkatan beban kerja.

Data awal yang diperoleh oleh peneliti dari Rumah Sakit Jiwa Banda Aceh tahun 2011 diketahui bahwa jumlah perawat di Rumah Sakit Jiwa berjumlah 195 orang sedangkan jumlah pasien yang masuk pada tahun 2011 mencapai 2.658 
orang. Rasio perawat terhadap pasien yang ideal untuk rumah sakit tipe A adalah $1: 3$ (Kepmenkes RI 262/ Menkes /7 / 1979 tentang jumlah perawat berdasarkan perbandingan tempat tidur rumah sakit). Namun hal ini belum dapat dilakukan oleh Rumah Sakit Jiwa Banda Aceh.

Berdasarkan pemaparan di atas maka dapat disimpulkan bahwa jumlah pasien yang masuk tidak sebanding dengan jumlah perawat yang ada di Rumah Sakit Jiwa Banda Aceh. Hal ini menyebabkan beban kerja perawat semakin berat yang dapat berdampak pada stres kerja.

\section{STRES KERJA}

Stres kerja menurut Greenberg (2004) adalah kombinasi dari sumbersumber stres pada pekerjaan, karakteristik individu, dan stresor ekstra organisasi. Interaksi stresor kerja dengan karakteristik individu, merupakan bagian yang penting di tempat kerja karakteristik ini termasuk : tingkat kecemasan dan neurotik pekerja, toleransi terhadap ambiguitas, dan pola kepribadian. Stres kerja dapat dimaksudkan sebagai suatu persepsi dari tenaga kerja akan adanya ancaman atau tantangan yang menggerakkan, menyiagakan atau membuat aktif dirinya. Tenaga kerja dapat merasakan lingkungan kerjanya sebagai suatu ancaman atau suatu tantangan (Anoraga, 2006).

Menurut Ivancenvich dan Matteson (dalam Luthans, 2006) mendefinisikan stres kerja sebagai respons adaptif yang dihubungkan oleh perbedaan individu dan atau proses psikologi yang merupakan konsekuensi tindakan, situasi, atau kejadian eksternal (lingkungan) yang menempatkan tuntutan psikologis dan atau fisik secara berlebihan pada seseorang. Dalam definisi lain, Beehr dan Newman (dalam Luthans, 2006) menyatakan stres kerja sebagai kondisi yang muncul dari interaksi antara manusia dan pekerjaan serta dikarakterisasikan oleh perubahan manusia yang memaksa mereka menyimpang dari fungsi normal mereka.
Menurut Fraser (dalam Anoraga, 2006) mengemukakan stres kerja adalah stres yang timbul karena adanya perubahan dalam keseimbangan sebuah kompleksitas antara manusia-mesin dan lingkungan. Fraser mengelompokkan dua macam pekerjaan yang sedikit banyak dapat menimbulkan stres, yakni pekerjaan yang terutama menuntut kekuatan fisik (pekerjaan dengan otot), dan pekerjaan yang terutama menuntut keterampilan atau kemahiran (pekerjaan dengan keterampilan).

Menurut Kitchel (dalam Wibowo, 2008) stres kerja merupakan respons fisik dan emosional pada kondisi kerja yang berbahaya, termasuk lingkungan di mana pekerjaan memerlukan kapabilitas, sumber daya, atau kebutuhan pekerja lebih banyak. Stres yang terjadi di tempat kerja menyebabkan organisasi menanggung beban : (1) rendahnya kualitas pelayanan; (2) pergantian staf yang tinggi; (3) reputasi perusahaan menjadi buruk; (4) citra perusahaan menjadi buruk; dan (5) ketidakpuasan pekerja (Wibowo, 2008).

Berdasarkan beberapa pendapat para ahli diatas dapat diambil kesimpulan bahwa stres kerja merupakan suatu kondisi negatif dimana seseorang mengalami ketegangan yang mempengaruhi aspek kognisi, afeksi, fisiologis, interpersonal dan organisasional pada pekerja yang disebabkan karena adanya tuntutan dalam menyelesaikan suatu tugas di lingkungan kerja.

Menurut Abraham dan Shanley (dalam Sunaryo, 2004) menemukan lima sumber stres dalam keperawatan, yaitu:

a. Beban kerja berlebihan, misalnya merawat terlalu banyak pasien, mengalami kesulitan dalam mempertahankan standar yang tinggi, merasa tidak mampu memberi dukungan yang dibutuhkan teman sekerja, dan menghadapi keterbatasan tenaga.

b. Kesulitan menjalin hubungan dengan staf lain, misalnya mengalami konflik dengan teman sejawat, mengetahui 
orang lain tidak menghargai sumbangsih yang dilakukan, dan gagal membentuk tim kerja dengan staf.

c. Kesulitaan dalam merawat pasten kritis, misalnya kesulitan menjalankan peralatan yang belum dikenal, mengelola prosedur atau tindakan baru, dan bekerja dengan dokter yang menuntut jawaban dan tindakan cepat.

d. Berurusan dengan pengobatan/perawatan pasien, misalnya bekerja dengan dokter yang tidak memahami kebutuhan sosial dan emosional pasien, terlibat dalam ketidaksepakatan pada program tindakan, merasa tidak pasti sejauh mana harus memberi informasi pada pasien atau keluarga, dan merawat pasien sulit atau tidak kerja sama.

e. Merawat pasien yang gagal untuk membaik, misalnya pasien lansia, pasien yang nyeri kronis, dan pasien yang meninggal selama merawat.

Berdasarkan hasil survei yang dilakukan Dewe (1989) di Amerika Serikat (dalam Sunaryo, 2004), sumber stres kerja dalam keperawatan salah satunya yaitu beban kerja berlebihan, seperti merawat pasien yang terlalu banyak. Hal ini diperkirakan juga dialami oleh para perawat yang bertugas di Aceh.

Perawat sebagai salah satu pemberi pelayanan kesehatan yang paling sering berhadapan dengan pasien yang penyakitnya beragam juga harus menghadapi keluarga pasien. Situasi ini memungkinkan perawat untuk mengalami stres yang akan berdampak pada pelayanan yang diberikan dan juga akan mempengaruhi perilaku kerja mereka (Iswanto \& Purwanti, 2008). Hal tersebut didukung oleh hasil wawancara nonformal yang dilakukan oleh peneliti pada beberapa perawat di Rumah Sakit Jiwa, terkait stres yang terjadi di lingkungan kerja. Beberapa perawat mengeluh harus merawat banyak pasien karena jumlah perawat yang tidak sebanding dengan jumlah pasien. Selain itu mereka juga harus selalu memperhatikan berbagai kebutuhan pasien gangguan jiwa, seperti memberi makan dan memberi obat pasien, mengawasi pasien mandi juga merupakan tugas perawat jiwa. Sebagian perawat juga mengeluh ada perasaan cemas ketika harus menghadapi pasien gangguan jiwa dengan tingkah laku yang tidak dapat diprediksikan.

Kondisi stres yang dialami perawat, diperkirakan dapat menimbulkan dampak negatif. Menurut Rice (dalam Waluyo, 2009) pada umumnya stres kerja lebih banyak merugikan diri karyawan maupun perusahaan. Pada diri karyawan, konsekuensi tersebut dapat berupa menurunnya gairah kerja, kecemasan yang tinggi, frustasi dan sebagainya. Konsekuensi pada karyawan ini tidak hanya berhubungan dengan aktivitas kerja saja, tetapi dapat memperluas ke aktivitas lain di luar pekerjaan. Seperti tidak dapat tidur dengan tenang, selera makan berkurang, kurang mampu berkonsentrasi, dan sebagainya (Waluyo, 2009).

Stres dapat menimbulkan dampak negatif bagi individu. Konsekuensikonsekuensi negatif berbentuk perilaku, bersifat psikologis, atau medis. Dari segi perilaku, misalnya stres menimbulkan tindakan-tindakan yang merusak atau berbahaya, seperti merokok, minum alkohol, makan terlalu banyak, dan terlibat narkoba. Perilaku-perilaku lain yang dipicu oleh stres adalah kecelakaan, kekerasan terhadap diri sendiri atau orang lain, serta gangguan makan. (Griffin, 2003).

Tuntutan tugas dalam menyelesaikan pekerjaan dari suatu organisasi merupakan sumber stres lain bagi perawat sehingga dibutuhkan suatu keterampilan manajemen emosi, agar tidak menurunkan produktivitas kerja. Keterampilan tersebut lebih dikenal dengan kecerdasan emosional.

\section{KECERDASAN EMOSIONAL}

Istilah kecerdasan emosi pertama kali digunakan pada tahun 1990 oleh 
Solevey dan Meyer yang kemudian dipopulerkan oleh Goleman. Cooper dan Sawaf (2002) berpendapat bahwa kecerdasan emosi adalah kemampuan merasakan, memahami dan menerapkan secara efektif daya dan kepekaan emosi sebagai sumber energi, informasi, koneksi dan pengaruh yang manusiawi. Suharsono (2004) juga menambahkan kecerdasan emosional tidak hanya berfungsi untuk pengendalian diri, tetapi juga mencerminkan kemampuan dalam mengelola ide, konsep, karya, maupun produk.

Menurut Salovey dan Meyer (dalam Mubayidh, 2006) mendefinisikan kecerdasan emosional sebagai suatu kecerdasan sosial yang berkaitan dengan kemampuan seseorang dalam memantau baik emosi dirinya maupun emosi orang lain, dimana kemampuan ini digunakannya untuk mengarahkan pola pikir dan perilakunya.

Weisinger (2006) mengemukakan

bahwa kecerdasaan emosi adalah menggunakan emosi secara cerdas, yaitu seseorang membuat emosi menjadi bermanfaat dengan menggunakannya sebagai pemandu perilaku dan pemikiran sehingga terdapat hasil yang meningkat dalam diri seseorang tersebut. Menurut Goleman (2007) menjelaskan bahwa kecerdasan emosi sebagai kemampuan untuk memotivasi diri sendiri dan bertahan menghadapi frustasi, mengendalikan dorongan hati dan tidak melebih-lebihkan kesenangan, mengatur suasana hati dan menjaga agar beban stres tidak melumpuhkan kemampuan berpikir, berempati dan berdo'a.

Berdasarkan beberapa pendapat para ahli diatas maka dapat diambil kesimpulan bahwa kecerdasan emosi adalah kemampuan individu dalam mengenali, memahami perasaan dirinya dan orang lain, mengendalikan perasaannya sendiri, menjalin hubungan serta memotivasi diri sendiri untuk menjadi lebih baik.
Goleman (2007) menempatkan kecerdasan pribadi Gardner sebagai definisi dasar tentang kecerdasan emosi dan memperluas kemampuan tersebut ke dalam lima aspek utama yaitu:

a. Kesadaran diri, yaitu kemampuan individu untuk menyadari dan memahami keseluruhan proses yang terjadi di dalam dirinya, perasaan, pikiran, dan latar belakang dari tindakannya. Individu mampu terhubung dengan emosi-emosinya dan pikiran-pikirannya sehingga ia mampu menamakan setiap emosi yang muncul. Aspek ini merupakan dasar dari seluruh aspek-aspek lainnya dimana kesadaran diri akan membantu tercapainya aspekaspek yang lain. Menurut Mayer (dalam Goleman, 2007) kesadaran diri adalah waspada terhadap suasana hati maupun pikiran tentang suasana hati, bila kurang waspada maka individu menjadi mudah larut dalam aliran emosi dan dikuasai oleh emosi. Kesadaran diri memang belum menjamin penguasaan emosi, namun merupakan salah satu prasyarat penting untuk mengendalikan emosi sehingga individu mudah menguasai emosi.

b. Pengaturan diri, yaitu kemampuan individu untuk mengelola, menyeimbangkan emosi-emosi yang dialaminya, dan menangani perasaan agar perasaan dapat terungkap dengan tepat, hal ini merupakan kecakapan yang sangat bergantung pada kesadaran diri.

c. Motivasi, yaitu kemampuan individu untuk memotivasi diri ketika berada dalam keadaan putus asa, mampu berpikir positif, dan menumbuhkan optimisme dalam hidupnya. Kemampuan ini akan membuat individu mampu bertahan, tidak putus asa dan kehilangan harapan ketika menghadapi masalah.

d. Empati, yaitu kemampuan individu untuk memahami perasaan, pikiran dan tindakan orang lain berdasarkan sudut pandang orang tersebut. Empati 
berkaitan dengan kemampuan individu untuk memahami perasaan terdalam orang lain sehingga individu mampu bertanggung rasa dan mampu membaca, memahami perasaan, pikiran orang lain hanya dari bahasa non-verbal, ekspresi wajah atau intonasi orang tersebut.

e. Membina hubungan dengan orang lain, yaitu kemampuan individu untuk membangun hubungan secara efektif dengan orang lain, mampu mempertahankan hubungan sosial tersebut, dan mampu menangani konflik-konfilk interpersonal secara efektif. Individu yang memiliki kemampuan ini akan mudah berinteraksi dengan orang lain dan senantiasa menghormati hak-hak orang lain. Kemampuan dalam membina hubungan merupakan suatu keterampilan yang menunjang popularitas, kepemimpinan dan keberhasilan antar pribadi (Goleman, 2007).

Perawat yang memiliki kecerdasan emosional yang tinggi senantiasa mampu mengendalikan emosinya dan cenderung akan lebih mudah bergaul dengan orangorang baru, sehingga akan dapat menurunkan tingkat stres kerja yang tinggi. Mengendalikan emosi berarti mampu mengetahui kapan saatnya ia harus mengambil tindakan yang tepat dalam situasi tertentu (Bahaudin, 2003). Sedangkan perawat yang tidak mampu menguasai emosinya kemungkinan besar hal ini akan berdampak pada pelayanan atau asuhan keperawatan yang diberikan kepada pasien.

Berdasarkan uraian diatas, dapat disimpulkan bahwa kecerdasan emosi berkaitan erat terhadap kemampuan mengatasi stres pada perawat. Penelitian ini bertujuan urntuk melihat hubungan antara kecerdasan emosi dengan stres kerja pada perawat di Rumah Sakit Jiwa Banda Aceh.

\section{METODE PENELITIAN}

Identifikasi Variabel Penelitian

Variabel yang akan diteliti dalam penelitian ini terdiri dari dua variabel, variabel independent dan variabel dependent, yaitu :

1. Variabel Independent (X) : Kecerdasan Emosi

2. Variabel Dependent (Y) : Stres Kerja

\section{Subjek Penelitian}

Penelitian ini menggunakan teknik acak sederhana (simple random sampling), yang melibatkan 100 perawat diruang rawat inap Rumah Sakit Jiwa Banda Aceh dengan kriteria : perawat yang terlibat langsung dalam memberikan asuhan keperawatan pada pasien di Rumah Sakit Jiwa Banda Aceh, status perawat sebagai pegawai negeri sipil dan tidak sedang cuti.

\section{Metode Pengumpulan Data}

Metode pengumpulan data dalam penelitian ini adalah dengan menggunakan skala psikologi. Skala menunjuk pada sebuah instrumen pengumpulan data yang bentuknya seperti daftar cocok tetapi alternatif yang disediakan merupakan sesuatu yang berjenjang. Skala banyak digunakan untuk mengukur aspek-aspek kepribadian atau aspek kejiwaan yang lain (Arikunto, 2010). Penelitian ini menggunakan dua skala psikologi, yaitu : skala kecerdasan emosi dan skala stres kerja.

\section{Skala Kecerdasan Emosi}

Kecerdasan emosi diungkap melalui skala kecerdasan emosi yang disusun oleh peneliti berdasarkan aspek menurut teori Goleman (2007), yaitu : kesadaran diri, pengaturan diri, memotivasi diri, empati,dan membina hubungan dengan orang lain.

Model skala yang digunakan adalah penskalaan model Likert yakni Sangat Sesuai (SS) diberi skor 5, Sesuai (S) diberi skor 4, Netral (N) diberi skor 3, Tidak Sesuai (S) diberi skor 2 dan Sangat Tidak 
Sesuai (STS) diberi skor 1 untuk aitemaitem favorable, sedangkan untuk aitem unfavorable Sangat Sesuai (SS) diberi skor 1, Sesuai (S) diberi skor 2, Netral (N) diberi skor 3, Tidak Sesuai (TS) diberi skor 4 dan Sangat Tidak Sesuai (STS) diberi skor 5. Skor skala ini menunjukkan bahwa semakin tinggi skor jawaban maka semakin tinggi kecerdasan emosinya (Azwar, 2010).

\section{Skala Stres Kerja}

Stres Kerja diungkap melalui skala stres kerja yang disusun oleh peneliti berdasarkan teori Rice (dalam Safaria \& Saputra, 2009), menggolongkan reaksi stres pada individu menjadi beberapa gejala, yaitu : gejala fisiologis, gejala emosional, gejala kognitif, gejala interpersonal dan gejala organisasional.

Model skala yang digunakan adalah penskalaan model Likert yakni Sangat Sering (SS) diberi skor 5, Sering (S) diberi skor 4, Kadang-kadang (K) diberi skor 3, Tidak Sering (S) diberi skor 2 dan Sangat Tidak Sering (STS) diberi skor 1 untuk aitem-aitem favorable, sedangkan untuk aitem unfavorable Sangat Sering (SS) diberi skor 1, Sering (S) diberi skor 2, Kadang-kadang (K) diberi skor 3, Tidak
Sering (TS) diberi skor 4 dan Sangat Tidak Sering (STS) diberi skor 5. Skor skala ini menunjukkan bahwa semakin tinggi skor jawaban maka semakin tinggi stres kerja yang dialami oleh perawat (Azwar, 2010).

\section{Metode Analisis Data}

Data yang diperoleh dalam penelitian diolah menggunakan teknik analisis statistik korelasi Pearson untuk mengetahui hubungan antara kecerdasan emosi dengan stres kerja pada perawat di Rumah Sakit Jiwa Banda Aceh. Perhitungan dalam penelitian ini dianalisis menggunakan komputerisasi dengan bantuan program SPSS (Statistical Product and Service Solution) 16.0 for Windows.

\section{ANALISIS DAN HASIL \\ Deskripsi Data Hasil Penelitian}

Setelah dilakukan analisis secara deskriptif, terdapat perbandingan antara hasil penelitian hipotetik (yang mungkin terjadi) dan hasil penelitian empirik (berdasar kenyataan di lapangan). Deskripsi data hasil penelitian dapat dilihat melalui tabel berikut :

Tabel 2. Deskripsi Hasil Data Penelitian

\begin{tabular}{lccccccccc}
\hline Variabel & \multicolumn{4}{c}{ Data Hipotetik } & \multicolumn{5}{c}{ Data Empirik } \\
\cline { 2 - 10 } & Xmaks & Xmin & Mean & SD & Xmaks & Xmin & Mean & SD \\
\cline { 2 - 9 } Kecerdasan Emosi & 145 & 29 & 87 & 19.33 & 134 & 78 & 113.83 & 12.138 \\
Stres Kerja & 165 & 33 & 99 & 22 & 105 & 43 & 73.59 & 15.632 \\
\hline
\end{tabular}

Kedua deskripsi hasil data penelitian tersebut dapat dijadikan batasan dalam pengkategorian subjek yang terdiri dari dua kategori yaitu rendah dan tinggi. Tabel normatif untuk pengkategorian subjek dalam penelitian ini berdasarkan data empirik pada dua variabel, yaitu variabel kecerdasan emosi dan stres kerja. Peneliti melakukan kategorisasi skor tiaptiap subjek penelitian pada masing-masing variabel penelitian. Hasil kategorisasi tersebut dapat dilihat pada tabel 3 
Tabel 3. Kategorisasi Tingkat Kecerdasan Emosi dan Stres Kerja Pada Perawat di Rumah Sakit Jiwa Banda Aceh

\begin{tabular}{cllll}
\hline Variabel & Kategori & Interval & Frekuensi & Presentase \\
\hline Kecerdasan & Rendah & $\mathrm{X}<113.83$ & 36 & $36 \%$ \\
Emosi & Tinggi & $113.83 \leq \mathrm{X}$ & 64 & $64 \%$ \\
\hline \multirow{2}{*}{ Stres Kerja } & Rendah & $\mathrm{X}<73.59$ & 54 & $54 \%$ \\
& Tinggi & $73.59 \leq \mathrm{X}$ & 46 & $46 \%$ \\
\hline & & Jumlah & $\mathbf{1 0 0}$ & $\mathbf{1 0 0 \%}$ \\
\hline
\end{tabular}

Berdasarkan tabel 3, diketahui bahwa dari 100 subjek (perawat di Rumah Sakit Jiwa) diketahui bahwa kecerdasan emosi pada perawat Rumah Sakit Jiwa sebesar 36 persen pada kategori rendah, dan 64 persen pada kategori tinggi. Hasil kategorisasi ini menunjukkan bahwa umumnya perawat di Rumah Sakit Jiwa memiliki kecerdasan emosi yang tinggi. Sementara itu, stres kerja pada perawat Rumah Sakit Jiwa sebanyak 54 perawat dengan skor persentase $54 \%$ pada kategori rendah, dan 46 perawat dengan skor persentase $46 \%$ berada pada kategori tinggi. Hal ini mengartikan bahwa perawat di Rumah Sakit Jiwa umumnya memiliki stres kerja yang rendah.

\section{Uji Asumsi}

Hasil uji normalitas yang dilakukan pada 100 orang responden penelitian menunjukkan pada variabel kecerdasan emosi memiliki sebaran yang normal (K-S Z $=0.124$, dengan $\mathrm{p}>0.05$ ). Variabel stres kerja memiliki sebaran yang juga normal yang ditunjukkan oleh nilai (K-S $\mathrm{Z}=0.322$, dengan $\mathrm{p}>0.05$ ), maka data dinyatakan terdistribusi normal. Selanjutnya, hasil uji linearitas berdasarkan output pada ANOVA tabel menunjukkan nilai signifikansi pada linearitas sebesar 0.000 . Signifikansi kurang dari $0.05(0.000<0.05)$, maka dapat disimpulkan bahwa antara variabel kecerdasan emosi dengan stres kerja terdapat hubungan yang linear.

\section{Uji Hipotesis}

Untuk menguji hipotesis penelitian apakah ada hubungan antara kecerdasan emosi dengan stres kerja pada perawat di Rumah Sakit Jiwa Banda Aceh, maka peneliti menggunakan analisis korelasi product moment dari Pearson. Hasil analisis korelasi product moment dari Pearson menunjukkan adanya korelasi yang negatif antara kecerdasan emosi dengan stres kerja pada perawat di Rumah Sakit Jiwa Banda Aceh dengan koefisien $(r)=-0.584$ dengan $p=0.00,(p<0.01)$. Hasil tersebut menunjukkan bahwa hubungan antara kedua variabel negatif signifikan, karena $\mathrm{p}<0.01$. Jadi jika variabel $\mathrm{X}$ tinggi maka variabel $\mathrm{Y}$ rendah, artinya semakin meningkat kecerdasan emosi pada perawat maka semakin menurun tingkat stres kerja pada perawat tersebut, begitu pula sebaliknya semakin rendah kecerdasan emosi perawat maka semakin tinggi tingkat stres kerja pada perawat tersebut.

\section{Analisa Per Aspek}

Setelah melakukan uji hipotesis untuk melihat hubungan antara kecerdasan emosi dengan stres kerja, peneliti juga melakukan analisis per-aspek pada variabel penelitian untuk melihat aspek mana yang sangat berhubungan dengan setiap variabel penelitian. Berikut merupakan hasil analisis variabel peraspek : 
Tabel 4. Korelasi aspek kecerdasan emosi dengan stres kerja

\begin{tabular}{lcc}
\hline Aspek-aspek Kecerdasan Emosi & $\begin{array}{c}\text { Korelasi dengan } \\
\text { Variabel Stres Kerja }\end{array}$ & Signifikansi \\
\hline Kesadaran Diri & -0.601 & $\mathrm{p}<0.01$ \\
Pengaturan Diri & -0.404 & $\mathrm{p}<0.01$ \\
Memotivasi Diri & -0.573 & $\mathrm{p}<0.01$ \\
Empati & -0.476 & $\mathrm{p}<0.01$ \\
Membina hubungan dengan orang lain & -0.314 & $\mathrm{p}<0.01$ \\
\hline
\end{tabular}

Berdasarkan tabel 6, tampak bahwa aspek dari variabel kecerdasan emosi yang mempunyai hubungan yang paling erat dengan variabel stres kerja adalah aspek kesadaran diri dengan angka korelasi -0.601 dengan $\mathrm{p}=0.000(\mathrm{p}<0.01)$. Artinya, terdapat hubungan yang negatif dan signifikan antara kecerdasan emosi dengan stres kerja. Hal ini berarti bahwa aspek kesadaran diri memiliki nilai korelasi yang cukup kuat dalam menurunkan stres kerja pada perawat di Rumah Sakit Jiwa Banda Aceh.

\section{DISKUSI}

Hasil analisis didapatkan bahwa ada hubungan negatif yang signifikan antara kecerdasan emosi dengan stres kerja pada perawat di Rumah Sakit Jiwa Banda Aceh yang ditunjukkan oleh hasil korelasi antara kecerdasan emosi dengan stres kerja dengan angka sebesar -0.584 dengan $\mathrm{p}=$ 0.00 , dinyatakan dengan signifikan karena $\mathrm{p}<0.01$. Artinya, apabila kecerdasan emosi tinggi maka stres kerja perawat di Rumah Sakit Jiwa akan rendah begitu juga sebaliknya jika kecerdasan emosi rendah maka stres kerja perawat di Rumah Sakit Jiwa akan tinggi, berdasarkan hasil tersebut maka dapat dinyatakan bahwa hipotesis diterima.

Hasil uji hipotesis pada penelitian ini menunjukkan bahwa rendahnya kecerdasan emosi merupakan salah satu faktor yang dapat menyebabkan stres kerja pada perawat di Rumah sakit Jiwa Banda Aceh. Hal ini sejalan dengan pendapat Goleman (2007) yang menyatakan bahwa individu yang memiliki kecerdasan emosi akan mampu mengendalikan hal-hal negatif seperti mudah marah, mudah tersinggung sampai tindakan agresif baik secara fisik maupun verbal. Salovey dan Meyer (dalam Goleman 2007) juga menyatakan kecerdasan emosi berkaitan dengan kemampuan seseorang dalam memantau emosi baik dirinya maupun emosi orang lain, dimana kemampuan ini digunakannya untuk mengarahkan pola pikir dan perilakunya.

Hasil penelitian yang dilakukan oleh Oryza dan Suseno (2009) menyatakan bahwa terdapat hubungan negatif yang signifikan antara kecerdasan emosional dengan stres kerja. Pendapat lainnya yang disampaikan oleh Rosalina (2008), mengatakan bahwa kecerdasan emosi pada perawat akan sangat menentukan perilaku melayani pasien, karena perawat yang memiliki kecerdasan emosi yang baik dapat mengontrol emosi-emosinya pada saat berinteraksi langsung dengan pasien maupun keluarganya.

Hasil penelitian lainnya yang dilakukan oleh Maria, Landa dan Zafra (2007) yang menyatakan bahwa kecerdasan emosi secara signifikan dapat menurunkan stres kerja pada perawat. Perawat sebagai profesi yang berorientasi kepada pelayanan jasa memerlukan suatu keterampilan dalam mengelola emosinya. Keterampilan penguasaan emosi sangat berpengaruh terhadap kinerja. Oleh karena itu kecerdasan emosi memberikan kontribusi dalam mengatur suasana hati dan menjaga agar stres tidak melumpuhkan kemampuan berpikir sehingga individu mampu untuk 
menyelesaikan konflik serta menjaga kinerja tetap stabil (Nurhidayah, 2006).

Berdasarkan temuan di lapangan, beban kerja perawat diruang rawat inap lebih tinggi. Perawat di ruangan melaksanakan asuhan keperawatan selama 24 jam dan bekerja secara bergiliran/shift jaga. Kemudian perawat diruang rawat inap juga dituntut harus tetap ada disisi pasien untuk melakukan berbagai hal yang berkaitan dengan perawatan pasien, seperti pelayanan yang diberikan dalam keadaan sakit ringan ataupun berat yang memerlukan pemantauan serta tindakan yang terus menerus sehingga dibutuhkan kecerdasan emosi yang tinggi untuk mengantisipasi stres kerja di Rumah Sakit Jiwa.

Berdasarkan hasil analisis menunjukkan bahwa sumbangan relatif antara kecerdasan emosi dengan stres kerja adalah $\mathrm{r}^{2}=0.341=34 \%$ dan $66 \%$ lainnya bisa disebabkan oleh variabel-variabel lain yang tidak terlibat dalam penelitian ini. Adapun variabel-variabel lain yang berhubungan dengan stres kerja selain kecerdasan emosi diantaranya adalah penelitian yang dilakukan oleh Noorbakhsh, Besharat \& Zarei (2010) dengan melibatkan variabel pemilihan strategi coping. Noorbakhsh, Besharat \& Zarei menyebutkan bahwa stres kerja dapat diturunkan apabila individu memiliki strategi coping yang sesuai dengan dirinya baik itu dengan coping yang berfokus pada masalah (problem focused coping) dan (emotion focused coping). Fungsi dari coping adalah untuk mengurangi tekanan atau meningkatkan ketrampilan dalam manajemen stres. Variabel lainnya seperti adanya dukungan sosial, locus of control, kepripadian tipe A dan $\mathrm{B}$, serta harga diri yang dikemukakan oleh Wijono (2011) variabel-variabel tersebut berkorelasi dalam menurunkan stres kerja yang dihadapi oleh individu. Wijono (2011) juga menyatakan pemberian konseling atau psikoterapi bisa digunakan untuk membantu individu menemukan masalah dan sumber-sumber ketegangan yang dapat menimbulkan stres kerja, menolong mengubah pandangan seseorang terhadap kondisi, situasi atau peristiwa yang menimbulkan stres kerja dan mengembangkan berbagai alternatif untuk menentukan strategi yang paling tepat dalam menghadapi stres kerja.

Aspek kecerdasan emosi yang memberikan konstribusi paling besar terhadap rendahnya perilaku stres kerja adalah aspek kesadaran diri dengan korelasi sebesar $\mathrm{r}=-0.601$ dan tingkat signifikansi $\mathrm{p}=0.000(\mathrm{p}<0.01)$. Artinya perawat Rumah Sakit Jiwa umumnya memiliki kecerdasan emosi yang tinggi apabila mampu untuk menyadari dan memahami keseluruhan proses yang terjadi di dalam dirinya, perasaan, pikiran, dan latar belakang dari tindakannya. Perawat mampu terhubung dengan emosi-emosinya dan pikiran-pikirannya sehingga ia mampu menamakan setiap emosi yang muncul.

Menurut Goleman (2007) dengan adanya kesadaran diri maka seseorang dapat mengetahui keadaan mereka, dan dengan mengetahui keadaannya maka dapat mengubah perilakunya menjadi lebih baik. Kesadaran diri bertujuan untuk membantu menjernihkan pikiran seseorang agar dapat mengendalikan emosi dan menghindari beban psikis dan stres kerja yang bersumber dari kondisi, situasi, atau peristiwa dalam pekerjaannya (Wijono, 2011).

Sebagai akhir pembahasan, perlu peneliti sampaikan bahwa pelaksanaan penelitian ini peneliti rasakan mengandung keterbatasasn-keterbatasan antara lain : penelitian ini menggunakan subjek yang terbatas yaitu hanya pada 100 orang perawat jiwa yang berada diruang rawat inap kemudian distribusi aitem skala kecerdasan emosi dan stres kerja tidak proposional sehingga mempunyai peluang untuk mempengaruhi hasil penelitian ini. Berdasarkan teori yang ada, banyak faktor yang mempengaruhi terjadinya stres kerja pada perawat, namun pada penelitian ini peneliti hanya sebatas mengkaji hubungan antara kecerdasan emosi dengan stres kerja 
pada perawat di Rumah Sakit Jiwa Banda Aceh.

\section{SIMPULAN}

Hasil penelitian menunjukkan terdapat hubungan negatif yang signifikan antara kecerdasan emosi dengan stres kerja pada perawat di Rumah Jiwa Banda Aceh dengan koefisien $(r)=-0.584$ dengan $\mathrm{p}=$ $0.00,(p<0.01)$. Semakin tinggi tingkat kecerdasan emosi perawat maka semakin rendah tingkat stres kerja. Sebaliknya semakin rendah tingkat kecerdasan emosi perawat maka semakin tinggi tingkat stres kerja. Berdasarkan hasil analisis menunjukkan bahwa sumbangan relatif antara kecerdasan emosi dengan stres kerja adalah $\mathrm{r}^{2}=0.341=34 \%$ dan $66 \%$ lainnya bisa disebabkan oleh variabel-variabel lain yang tidak terlibat dalam penelitian ini.

Penelitian ini juga bertujuan untuk melihat aspek kecerdasan emosi manakah yang memberikan kontribusi paling besar terhadap rendahnya stress kerja pada perawat di Rumah Sakit Jiwa Banda Aceh. Hasil penelitian menunjukkan bahwa kesadaran diri merupakan aspek yang memiliki kontribusi terbesar terhadap stres kerja. Hal ini berarti bahwa perawat akan memiliki kecerdasan emosi tinggi apabila ia mampu untuk menyadari, memahami dan mampu menamakan setiap emosi yang muncul sehingga dapat mengubah perilakunya ke arah yang lebih baik.

\section{SARAN}

Berdasarkan hasil penelitian, maka peneliti akan memberikan saran yang diharapkan dapat bermanfaat bagi pihak lain.

\section{Bagi subjek penelitian}

Bagi perawat Rumah Sakit Jiwa setelah terbukti ada hubungan antara kecerdasan emosi dengan stres kerja, maka diharapkan bagi perawat yang memiliki kecerdasan emosi yang tinggi agar dapat mempertahankan kondisi tersebut, yakni sebagai suatu langkah menghadapi berbagai situasi yang terjadi di tempat kerja khususnya dalam menghadapi stres di tempat kerja yaitu dengan kesadaran diri, kemampuan mengelola emosi, memotivasi diri, empati dan membina hubungan dengan orang lain.

2. Bagi Rumah Sakit Jiwa

Rumah Sakit Jiwa Banda Aceh perlu mengalokasikan dana untuk kegiatan merancang program pelatihan kecerdasan emosi yang difokuskan pada bidang Self Awareness, Self Management, Self Motivation dan Anger Management bagi perawat yang memiliki kecerdasan emosi rendah yang bertujuan untuk membantu perawat dalam melatih kemampuan mengontrol emosi sehingga perawat dapat menyelesaikan masalahnya tanpa harus menimbulkan stres yang nantinya akan menghambat kinerja perawat dalam memberikan pelayanan yang optimal kepada pasien. Selanjutnya bagi perawat yang memiliki stres kerja tinggi perlu dilakukan suatu upaya untuk mengurangi stres kerja seperti memberikan pelatihan teknik relaksasi.

3. Bagi peneliti selanjutnya

Dari hasil penelitian diperoleh data bahwa sumbangan relatif antara kecerdasan emosi dengan stres kerja adalah 34\% pada perawat di Rumah Sakit Jiwa Banda Aceh dan 66\% lainnya disebabkan oleh variabelvariabel lain sehingga bagi peneliti selanjutnya yang tertarik dengan permasalahan stres kerja disarankan untuk meneliti aspek lain yang mempengaruhi, seperti masa kerja perawat, lokasi kerja perawat (diruang rawat inap atau ruang rawat jalan), status kerja perawat (perawat pns atau kontrak).

\section{DAFTAR PUSTAKA}

Anonim. (2012). Buku Profil Badan Layanan Umum Daerah Rumah Sakit Jiwa Banda Aceh. Tidak Diterbitkan 
Agustian, A. G. (2007). Rahasia Sukses Membangun Kecerdasan Emosi dan Spiritual ESQ: Emotional Spiritual Quotient Berdasarkan 6 Rukun Iman dan 5 Rukun Islam. Jakarta: ARGA Publishing.

Anoraga, P. (2006). Psikologi Kerja. Jakarta : PT Asdi Mahasatya

Arikunto, S. (2010). Prosedur Penelitian Suatu Pendekatan Praktik. Jakarta : Penerbit Rineka Cipta

Azwar, S. (2010). Penyusunan Skala Psikologi. Yogyakarta : Pustaka Pelajar

Bahaudin, T. (2003). Brainware Management: Generasi Kelima Manajemen Manusia. Ed.4. Jakarta : PT Elex Media Komputindo

Cooper, R. K., \& Sawaf, A. (2002). Executive EQ: Kecerdasan Emosi dalam Kepemimpinan dan Organisasi. Penerjemah: Alex Tri Kantjono Widodo. Jakarta: PT Gramedia Pustaka Utama

Goleman, D. (2000). Emotional Intelligence: Kecerdasan Emosional Mengapa EI Lebih Penting Daripada IQ. Jakarta: PT Gramedia Pustaka Utama

Goleman, D. (2000). Working With Emotional Intelligence : Kecerdasan Emosi Untuk Mencapai Puncak Prestasi. Jakarta: PT Gramedia Pustaka Utama

Goleman, D. (2007). Emotional Intelligence: Kecerdasan Emosional Mengapa EI Lebih Penting Daripada IQ. Jakarta: PT Gramedia Pustaka Utama

Greenberg, J.S. (2004). Comprehensive Stress Management. Eight Edition. New York: McGraw-Hill

Griffin, R.W. (2003). Manajemen Edisi Tujuh Jilid Dua. Jakarta: Penerbit Erlangga

Iswanto, S \& Purwanti, S.O. (2008). Hubungan Stress Kerja Dengan Perilaku Medikasi Di Ruang Al-Qomar Dan Asy-Syam Rumah Sakit Islam Surakarta. Berita Ilmu Keperawatan Vol.1, No. 1, 76 Juni 2008, Halaman 76-82. Diakses 4 Juni 2011, dari http://publikasiilmiah.ums.ac.id/bitstrea $\mathrm{m} /$ handle/123456789/482/2e.pdf

Luthans, F. (2006). Perilaku Organisasi Edisi Sepuluh. Yogyakarta: Penerbit ANDI

Maria, J., Landa, A., Zafra E.L. (2007). The Relationship Between Emotional Intelligence, Occupational Stress And Health In Nurses: A Questionnaire
Survey. International Journal of Nursing Studies 45 888-901

Maysarah. (2008). Rumah Sakit Jiwa Banda Aceh Tema: Arsitektur Perilaku. Banda Aceh: Skripsi Universitas Syiah Kuala

Mubayidh, M. (2006). Kecerdasan dan Kesehatan Emosional Anak Referensi Penting Bagi Para Pendidik dan Orang Tua. Jakarta : Pustaka Al-Kautsar

Nggermanto, A. (2002). Quantum Quotient (Kecerdasan Quantum): Cara Cepat Melejitkan IQ, EQ dan SQ Secara Harmonis. Bandung: Penerbit Nuansa

Noorbakhsh, S.N, Besharat, M.A., \& Zarei, J. (2010). Emotional Intelligence And Coping Styles With Stress. Journal Procedia Social and Behavioral Sciences 5 818-822

Nurhidayah, R.E. (2006). Pentingnya Kecerdasan Emosional Bagi Perawat. Universitas Sumatera Utara: Jurnal Keperawatan Rufaidah Sumatera Utara, Volume 2 Nomor 1, Mei 2006. Diakses 4 Juni 2011, dari

repository.usu.ac.id/bitstream/123456789/.../ru f-mei20062\%20(5).pdf

Oryza, D.C.F., \& Suseno, M.N. (2009). Hubungan Antara Kecerdasan Emosional Dengan Stres Kerja Pada Perawat. Yogyakarta : Naskah Publikasi Universitas Islam Indonesia. Diakses 4 Juni 2011, dari psychology.uii.ac.id/images/stories/.../n askah-publikasi-03320069.pdf

Rosalina, W.L. (2008). Pengaruh Kecerdasan Emosional Perawat Terhadap Perilaku Melayani Konsumen dan Kinerja Perawat Rumah Sakit Umum Daerah Kabupaten IndraMayu. Jurnal Ekonomi dan Bisnis Vol. 2, No. 3, November 2008 Hal. 195-216. Diakses 4 Juni 2011, dari http://isjd.pdii.lipi.go.id/index.php/Searc h.html?act $=$ tampil\&id $=11338 \&$ idc $=38$

Safaria, T., \& Saputra, N. E. (2009). Manajemen Emosi : Sebuah Panduan Cerdas Bagaimana Mengelola Emosi Positif Dalam Hidup Anda. Jakarta : Bumi Aksara

Sunaryo. (2004). Psikologi Untuk Keperawatan. Jakarta : Penerbit Buku Kedokteran EGC

Waluyo, M. (2009). Psikologi Teknik Industri.Yogyakarta : Graha Ilmu 
Weisinger, H. (2006). Emotional Intelligence at Work. Penerjemah: Roro Ratih Ambarwati. Jakarta: PT Bhuana Ilmu Populer Kelompok Gramedia
Wibowo. (2008). Manajemen Perubahan Edisi Kedua. Jakarta : Rajawali Pers

Wijono, S. (2011). Psikologi Industri dan Organisasi: Edisi Revisi. Jakarta: Kencana Prenada Media Group 